\title{
Port Cooperation in the North Adriatic Ports
}

\author{
Stamatović, Kristijan; de Langen, Peter; Groznik, Aleš
}

Document Version

Accepted author manuscript

Published in:

Research in Transportation Business and Management

DOI:

10.1016/j.rtbm.2018.03.006

Publication date:

2018

License

CC BY-NC-ND

Citation for published version (APA):

Stamatović, K., de Langen, P., \& Groznik, A. (2018). Port Cooperation in the North Adriatic Ports. Research in Transportation Business and Management, 26, 109-121. https://doi.org/10.1016/j.rtbm.2018.03.006

Link to publication in CBS Research Portal

\section{General rights}

Copyright and moral rights for the publications made accessible in the public portal are retained by the authors and/or other copyright owners and it is a condition of accessing publications that users recognise and abide by the legal requirements associated with these rights.

Take down policy

If you believe that this document breaches copyright please contact us (research.lib@cbs.dk) providing details, and we will remove access to the work immediately and investigate your claim. 


\title{
Port Cooperation in the North Adriatic Ports
}

\section{Kristijan Stamatović, Peter de Langen, and Aleš Groznik}

\author{
Journal article (Accepted manuscript*)
}

\section{Please cite this article as:}

Stamatović, K., de Langen, P., \& Groznik, A. (2018). Port Cooperation in the North Adriatic Ports. Research in Transportation Business and Management, 26, 109-121. https://doi.org/10.1016/j.rtbm.2018.03.006

DOl: https://doi.org/10.1016/j.rtbm.2018.03.006

* This version of the article has been accepted for publication and undergone full peer review but has not been through the copyediting, typesetting, pagination and proofreading process, which may lead to differences between this version and the publisher's final version AKA Version of Record.

Uploaded to CBS Research Portal: August २०19

(C) २०19. This manuscript version is made available under the CL-BY-NC-ND 4.0 license http://creativecommons.org/licenses/by-nc-nd/4.0/ 


\title{
Port cooperation in the North Adriatic Ports
}

\begin{abstract}
Recent trends in port development show that ports are making increasing efforts to forge mutually beneficial cooperation strategies, particularly ports sharing a common hinterland. In this paper, we analyse the North Adriatic ports (Koper, Rijeka, Trieste and Venice) with a focus on two related themes. First, the complementarity of the North Adriatic (NA) ports in the container market is analysed based on port vessel service patterns and shipping line interviews. We operationalize the analysis of complementarity with an analysis of the effects of multiple port calls on the revenue required to make a call in a specific NA port economically feasible. We conclude that the inclusion of another NA port reduces the minimum required revenue for a call in an additional NA port.

Second, we assess the scope and depth of cooperation between ports. We map current and potential future cooperation using a 'cooperation matrix' with two dimensions: the involvement of stakeholders (limited vs. broad), and the depth of cooperation (pre-competitive vs. commercial). We use in-depth interviews with port authorities, terminal operators, rail operators, major shipping lines and forwarders in the NA region to position the NA ports in the matrix. We conclude by discussing prospects of future NAPA ports cooperation.
\end{abstract}

\section{Keywords}

Port cooperation; North Adriatic; Containers; Stakeholders

\section{Introduction}

The North Adriatic ports traditionally encompass four ports in three EU member countries, Trieste and Venice in Italy, Koper in Slovenia and Rijeka in Croatia. All four ports are members of the North Adriatic Port Association (and will henceforth be termed the "NAPA" ports). Ravenna, another Italian port, was also a member until 2012. Their exit from the association was attributed to the fact that Ravenna mainly serves the market of Italian region Emilia-Romagna and, unlike the previously mentioned ports, did not strive to serve the middle European hinterland. Ravenna re-joined the NAPA at the end of 2017. In the container segment, the focus of this paper, the NAPA ports jointly handled over 2 million TEU in 2016, up from slightly over 1 million TEU in 2007. This means the throughput has doubled in less than a decade. The growth is mainly achieved through attracting cargo that was previously shipped via ports in the Hamburg-Le Havre range (Notteboom, 2010). The NAPA region has attracted considerable attention from industry players in recent years, with e.g. a Drewry report (2016) concluding that the fastest route from the Far East to Munich is via Koper, with the MSC shipping line recently entering a joint venture with Trieste's container terminal (Trieste Marine Terminal-TMT), and finally, the sizeable amount of infrastructure development projects co-funded by the European Union in all four ports, mostly pertaining to enlarging and expanding container terminals and upgrading rail and intermodal links with Central and Eastern Europe. From the academic perspective, the NAPA region has been attracting greater research attention (see Twrdy and Batista, 2013; 2014; 2016; Acciaro et al., 2017). The NAPA's cooperation approach is to cooperate internationally and compete locally. However, as our analysis will reveal, the NAPA ports exhibit a low level of cooperation, especially on a strategic level.

Developments in the last decade have severely intensified the competitive landscape among ports. This has been caused by the concentration and consolidation among shipping lines and the increase in intermodality, which has enabled greater inter-range competition, as well as more recent initiatives such as "Belt and Road Initiative" (BRI), which is reviving the land trade route by rail between Asia and Europe (Casarini, 2016). These trends foster cooperation between ports, particularly those in adjacent areas. A number of authors have mentioned cooperation as a trend in the maritime industry (e.g. Notteboom, 1997; Wang, 1998; Li and Oh, 2010; Hwang and Chiang, 2010). The authors acknowledge that the type and format of cooperation are context-specific; nevertheless, most studies either categorize the types of possible cooperation (De Langen \& Nijdam, 2009) or provide a contextspecific analysis of port cooperation (Song, 2002; Yap and Lam, 2006; Hoshino, 2010). There have also 
been attempts to provide a universal framework for assessing the extent of cooperation between port authorities (McLauglin \& Fearon, 2013).

In this paper, we argue that complementarity among ports is a necessary condition for effective port cooperation among adjacent ports. This paper builds on the findings in the literature and contributes in two ways: first by enlarging the scope of analysed stakeholders. Previous research has focused mostly on port authorities and the benefits of their cooperation. However, cooperation is only effective in the long run, if it generates commercial advantages. Assessing the benefits of cooperation from a commercial perspective requires an analysis of the involvement of all firms in a port cluster in the cooperative initiatives. Thus, unlike previous studies, we consider not only cooperation between port authorities and explore several potential value-creating strategies among commercial operators in port clusters. The second contribution of this paper is the conceptual clarity we provide for analysing complementarity between ports.

In the next section, we review the main literature on port cooperation and in the section thereafter, we set up a theoretical research framework by developing a matrix to classify cases of cooperation between ports. We also present our research design to assess the level of cooperation in NAPA within this matrix. In the next section, we provide a brief description of the NAPA ports and assess their current level of cooperation, based on the results obtained from detailed interviews with the stakeholders. In the following section, we first establish the case for the complementarity of the NAPA ports and then discuss the future prospects of NAPA port cooperation. In the final section, we summarize the results and suggest additional research on this topic.

\section{$2 \quad$ Literature review}

Many scholars recognize that ports can no longer rely on serving captive hinterlands. Containerization has enabled greater intermodality, the expansion of international trade, the concentration of the shipping industry and the liberalization of transport markets, all of which has increased the intensity of port competition in shared hinterlands (Notteboom \& Winkelmans, 2001, Fageda, 2005, Seo \& Ha, 2010). In light of the maturation of container traffic, which is closely linked to the maturation of the global economy (Rodrigue et al., 2013), but also, in the light of recent trends in port growth and competition, there is an increasing need for ports, particularly those sharing common hinterland, to forge mutually beneficial cooperation strategies. Already in the late 90s, Noteboom (1997) predicted that due to the concentration tendency among shipping lines, the pressure on port authorities in terms of efficiencies and costs would grow and suggested that the only way to counterbalance that pressure is for ports and terminals to cooperate and form strategic alliances. The term co-opetition was originally coined by Noorda (1993), meaning a mixture of competition and cooperation, thus having a strategic implication that those engaged in the same or similar markets should consider a win-win strategy. Song (2002) introduced the term co-opetition to the maritime industry. He explained that ports should compete through cooperation, effectively achieving win-win situations by proposing joint ventures and crossshareholdership as the way forward. This is a sensible conclusion for ports that have complementary commercial interests. Jacobs (2007) observes that cooperation between Long Beach and Los Angeles ports seems prudent, since both ports depend on the same congested hinterland transport systems and face competition from other ports on the Pacific coast. De Langen and Nijdam (2009) identify three categories of cooperation among ports in proximity and show for the case of the Copenhagen-Malmö port that even cross-national port authority joint venture can be successful and mutually beneficial. Hoshino (2010) suggests that Japanese ports need to collaborate with one another to survive the harsh competition from the Chinese ports. In the absence of anti-trust regulation, Wang et al. (2012) wonder why ports choose to compete at all, since potential gains are larger when ports cooperate instead. Furthermore, government agencies often encourage cooperation among ports. Consolidation in the maritime industry has gone hand-in-hand with greater efficiencies through the introduction of everlarger vessels. Notteboom (2010) finds that compared to 1998, a weekly call in 2010 generated around three times more containers (around 300,000 TEU per year), due to the increasing ship size and associated increasing call size. The use of larger container ships provides an additional motive for 
cooperation, as ports that join forces may be better positioned to attract shipping lines. Moreover, ports in the wider regions become potential substitutes, thereby intensifying competition. Wang et al. (2012) argue that cross-shareholding or full mergers, if feasible, are the most optimal way to coordinate pricing and operational strategies in adjacent ports. Mclaughlin and Fearon (2013) agree that some form cooperation among adjacent ports is both favourable and appropriate, and note that mergers are more likely when they are part of a national economic agenda (e.g. China) or when the existence of ports is endangered by future prospects (e.g. Copenhagen-Malmö). Collaboration as a form of cooperation is feasible even when institutional inertia prevents mergers, joint ventures or cross-shareholding. Collaboration may be beneficial, while maintaining the identity and autonomy of the ports.

De Langen and Nijdam (2009) distinguish three levels of cooperation, namely: port authorities that have developed strategic cooperation with other port authorities in their vicinity in the form of joint holdings, investments and acquisitions; port authorities that have some form of cooperation, but not on a strategic level, and port authorities that do not have any form of cooperation with ports in their vicinity, despite being members of port associations (e.g. ESPO) or networks (e.g. Ecoports). Freemont and Lavaud-Letilleul (2009) distinguish between ports linked within a strait or an island, ports with different profiles and ports with similar profiles and argue the type of cooperation depends on the port profile. Freemont and Lavaud-Letilleul (2009) also argue that ports may change their profiles in cases when adjacent ports would consider building complementary relationships. For example, when one port has better nautical accessibility, while another has better terrestrial accessibility, ports could coordinate resources in a way to complement each other in their respective hindrances, thereby reducing the necessary investments. Mclauglin and Fearon (2013) provide a framework for assessing the extent of cooperation among ports in the form of a cooperation-competition matrix, which distinguishes the intensity of cooperation on one axis and the degree of competition on another axis. This framework allows them to assess whether and how intensive forms of cooperation can reduce competition.

\section{$3 \quad$ Research framework and research design}

\subsection{Port complementarity}

The core concept to assess the potential for commercial cooperation is complementarity. The term complementarity gained increased attention in microeconomics thanks largely to Milgrom and Roberts (see e.g. Milgrom, P., \& Roberts, J., 1990; Roberts, J., 2007). They define complementarity as a relationship between two or more elements so that each element enhances the value of the other. Notteboom's (2009) paper defines ports as complements and substitutes based on vessel calling patterns. If a container vessel in a specific loop calls at both ports (or at none of them), they are considered complements, if a container vessel calls at only one of the port pair in question, then they are considered substitutes. Notteboom finds that smaller ports typically act as complements to larger load centers, such as the case of Antwerp and Zeebrugge. However, Notteboom's operationalization of complementarity is not fully in line with the mainstream definition from Milgrom and Roberts (see above). A call pattern where a call at one port goes hand-in-hand with a call in another port may be because 'one element enhances the value of the other', but may also be because these ports are independent of each other. In addition, double call patterns at ports that are substitutes are possible. For instance, two nearby ports may have large volumes of captive cargo that justify a call in both ports, even though these ports continue to be substitutes for cargo destined for a common 'contestable hinterland'. ${ }^{1}$

In line with Merkel (2017), ${ }^{2}$ the complementarity of two port calls can be assessed by analysing two different effects:

\footnotetext{
${ }^{1}$ As one possible illustration: ships may call in Ningbo and Shanghai given the large captive volumes, but Ningbo and Shanghai can continue to be substitutes for transhipment cargo, as well as cargo for inland waterway destinations along the Yangtze river.

${ }^{2}$ Merkel's (2017) study shows the 'complementarity of demand' in the Mediterranean ports by assessing the evolution of quarterly traffic volumes in the Mediterranean ports. However, such demand complementary in our
} 
1) The 'substitution effect' of a reduction of the generalized port costs of port A on port B. This effect may be either not relevant or negative. In general, for competing ports, the effect will be negative, as lower generalized port costs of port A lead to a shift of cargo from port B to port A.

2) The 'demand effect' of a reduction of the generalized port costs of port A on port B. Such a demand effect may arise for two reasons:

i. The lower total generalized transport costs of port A make the whole transport network cheaper, leading to additional demand. ${ }^{3}$ This effect is very small, if not negligible, for a modest cost reduction of one individual port.

ii. A 'range shift effect', due to the increased attractiveness of the entire port range due to the reduced generalized transport costs in one port in that range. This may lead to a shift of volume for all ports in the range. Such a shift may occur because the lower generalized port costs of port $A$ either make shipping to the port range in which port $A$ and $B$ are located more attractive, compared to other transport modes, or make the port range of port $A$ and B more attractive compared to ports in other ranges. ${ }^{4}$

Given the above, the complementarity of call patterns (both ports A and B are called on) can in our view be regarded as a necessary but insufficient condition for complementarity. Ports can only be regarded as complementary when the sum of the two effects mentioned above (the substitution effect and the demand effect) of a reduction in the generalized costs of port $A$ is positive. This is the case when the additional volumes for port $B$, due to the positive effect of the improved competitive position of the range as a whole compared to other ports/modes, is larger than the negative substitution effect due to the shift of cargo from port B to port A. Only in this case, does port A benefit from the improved competitive position of port $B$ and vice versa. Whether or not that is the case for the NAPA is assessed in section 4.

\subsection{A 'Cooperation matrix' for classifying cases of port cooperation}

This paper expands the analysis of port cooperation by proposing a new classification of cooperation between ports. In line with the literature discussed in the previous section, our matrix consists of two dimensions (see Figure 1):

1) Commercial vs. Non-commercial cooperation. This distinction has previously been made, among others by De Langen and Nijdam (2009) and Donselaar and Kolkman (2010). We argue that, in a simplified way, this distinction is similar to the distinction between cooperation and coopetition (introduced to the ports industry by Song (see e.g. Song et al, 2015)). Co-opetition implies cooperation while simultaneously competing. In this model, cooperation generally

\footnotetext{
view does not necessarily imply that 'one element enhances the value of the other', but may be explained by the increasing economic integration of the Mediterranean economies leading to increasing volumes and increasingly similar economic cycles. Similarly, Twrdy and Batista's (2016) attempt to assess competition and complementarity based on past TEU volumes handled by the NAPA ports is in our view flawed, for one (as the authors themselves acknowledge) because of the capacity constraints that significantly affect the evolution of volumes and thus weaken the conclusions from their analysis.

${ }^{3}$ This can be considered as a version of the 'income effect': the higher global GDP (the equivalent for income of an individual) leads to additional trade, which positively affects all ports.

${ }^{4}$ As an example, the Great Lakes ports may be useful. Currently, the only significant container port in the Great Lakes area is Montreal. The development of an additional container port, for instance in Cleveland, would, alongside a possible 'substitution effect' (a shift of containers from Montreal to Cleveland), make the whole Great Lakes area a more competitive shipping destination. Thus, it may lead to a shift of cargo away from rail (for instance cargo with an origin or destination in Mexico, or the South of the US), and it may lead to a shift of cargo from the US East coast ports to the Great Lakes ports.
} 
focuses on non-competitive issues such as lobbying and environmental practices. Commercial cooperation leads to a shift away from competition, as joint propositions are developed. ${ }^{5}$

2) Cooperation confined to the port authority (or port development company) vs. Cooperation across relevant companies in the port cluster. While most studies of port cooperation (implicitly) focus on the port authority (or port development company - in any case, one single actor, which is mandated to develop the port), we argue that port cooperation potentially can be much broader and involve other relevant companies in the port, such as terminal operators, shipping lines, hinterland transport companies and logistic service providers (see Van der Horst and De Langen, 2008, for an overview of potential broader cooperative efforts in hinterland transport).

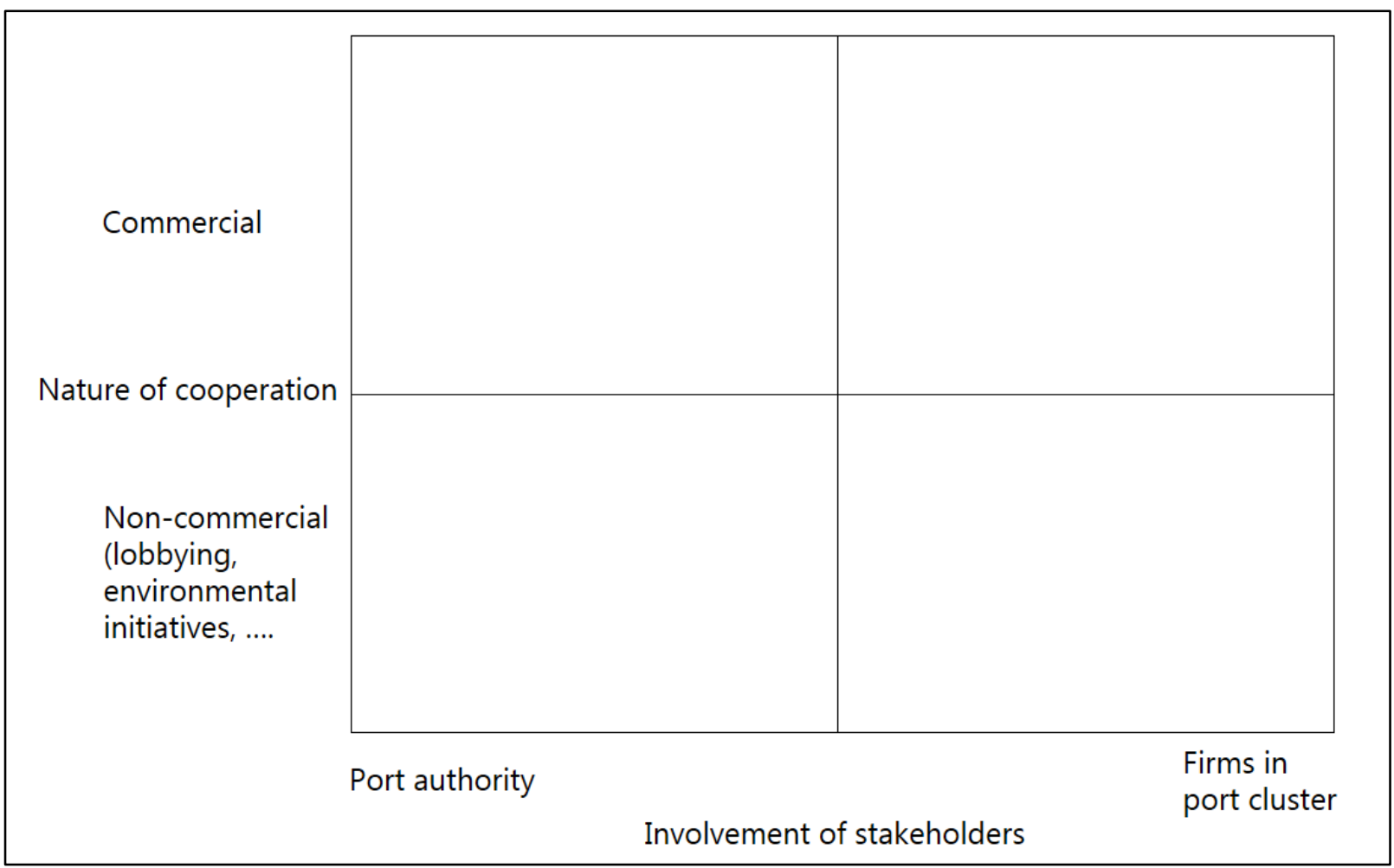

Figure 1: Cooperation matrix for classifying cases of port cooperation

In section 4 , this matrix is used to assess the case of cooperation in the NAPA.

\subsection{Research methodology}

The case analysis of the NAPA ports focuses on container cargo. We acknowledge that focusing solely on containers is a limitation of our analysis, ${ }^{6}$ since the results for one segment alone may not be (fully) representative of the level of cooperation among ports. There are several key reasons why our study considers containers only. Firstly, the share of tonnage throughput in containers among individual NAPA ports, with the clear exception of Trieste, is large (see Figure 2). Considering the NAPA as a whole,

\footnotetext{
${ }^{5}$ While in theory it would be possible for ports to compete in one segment and cooperate commercially in another, in practice, we are not aware of cases where this works.

${ }^{6}$ We also asked our respondents (see Appendix 1 b) question 14. to assess a hypothetical situation where NAPA ports would agree on which cargo type category each of them would specialize in, given their existing specializations and capabilities, and thus create an ideal cooperation strategy. Their answers were that such a strategy is unattainable, since, among others, no port would forgo the most profitable and growing cargo category containers.
} 
containers rank second after liquid cargo. ${ }^{7}$ Secondly, containers have been recognized as the most profitable market segment with the biggest growth potential for all ports, which is in line with the general industry trends where cargo is increasingly moving in containers (McKinsey \& Company, 2017). Finally, the expansion plans of the NAPA ports are mainly aimed at expanding container handling capacity. ${ }^{8}$

\begin{tabular}{|lrrr|r|r|}
\hline Cargo type split in \% of total & KOPER & VENICE & TRIESTE & RIJEKA & \multicolumn{2}{|c|}{$\begin{array}{l}\text { NAPA- } \\
\text { TOTAL }\end{array}$} \\
\hline Dry bulk & $35 \%$ & $32 \%$ & $1 \%$ & $38 \%$ & $17 \%$ \\
\hline Liquid bulk & $16 \%$ & $35 \%$ & $70 \%$ & $0 \%$ & $48 \%$ \\
\hline Containers & $37 \%$ & $22 \%$ & $11 \%$ & $41 \%$ & $20 \%$ \\
\hline Ro-Ro & $4 \%$ & $3 \%$ & $4 \%$ & $0 \%$ & $4 \%$ \\
\hline Other/General cargo & $7 \%$ & $9 \%$ & $13 \%$ & $20 \%$ & $11 \%$ \\
\hline
\end{tabular}

Figure 2: Cargo type throughput split in percentages of total tonnage throughput in a single port and the NAPA as an entire region in 2015 (source: Eurostat).

The research method consists of semi-structured expert interviews, as well as data analysis to assess whether or not the NAPA ports are complementary. We also use this data to assess the current level of cooperation and the future prospects of cooperation. We conducted a total of 15 interviews, part of which were executed in person and part by phone during the period of May-July 2017. Expert respondents were selected based on their position in their organization, as well as their length of tenure in the companies they represented. In most cases, this meant that either the CEOs of the companies (forwarders, intermodal operators), country or regional managers (carriers) and commissioners and/or heads of $R \& D$ units (port authorities and terminal operators) were identified as experts. In certain cases, there were more participants in the interview from one organization. In total, we interviewed country managers or commercial managers of five major shipping lines for the NAPA region, four port authority representatives (commissioners, heads of research departments), two major rail-intermodal operators present in the region and four CEOs of forwarders from Italy, Slovenia and Croatia (with a presence in at least two other countries). Questions that were prepared in advance were personalized for four categories (carriers, forwarders, intermodal operators and port authorities). All respondents were asked to assess the current level of cooperation among stakeholders, to point out issues preventing better cooperation and to provide potential solutions in overcoming these issues. Respondents were also asked to consider several hypothetical NAPA port situations, ${ }^{9}$ which were directed at confirming the issues that are hindering greater cooperation (see Appendix 1 for the lists of questions for all four interview categories). The respondent's answers were noted and, after their reply, an oral summary of the reply was given to confirm that our understanding of the answer was correct. Respondents were promised

\footnotetext{
${ }^{7}$ Controlling for the effect of Trieste's absolute weight of liquid cargo throughput, which is about $70 \%$ of the total tonnage throughput of all three other ports combined, containers would rank as the largest product category.

${ }^{8}$ See the development plans in Koper: http://www.sloveniatimes.com/port-of-koper-expanding-containercapacity and http://www.zivetispristaniscem.si/index.php?page=static\&item=17; Rijeka:

http://www.portauthority.hr/en/development projects/rijeka gateway project/container terminal brajdica; Trieste: http://www.oevz.com/en/news-en/expansion-plan-for-trieste-port-approved/; Venice:

https://www.port.venice.it/en/the-new-container-terminal.html-0 \& https://www.vesselfinder.com/news/2319Venice-plans-new-mega-port; [All accessed 27.01.2018]

${ }^{9}$ For example: if NAPA ports were in the same country and operated under the same legal and other frameworks, would there be more cooperation among them?
} 
anonymity, which the authors felt was necessary to allow the answers received to be as profound as possible. $^{10}$

The data analysis was performed by collecting shipping line calling patterns for the NAPA region, as well as ocean freight rates, hinterland connectivity and maritime connectivity. This data is publicly available except for data on freight rates, which was collected over a two year period by accessing the data of a forwarding company. ${ }^{11}$

\section{Complementarity and cooperation in the NAPA}

Based on the conceptual discussion of complementarity, interviews and data are used to assess complementarity.

The NAPA region (see Figure 3) has undergone important changes in recent years. Most importantly, major carriers and alliances increasingly offer direct services to and from the NAPA. Currently (autumn 2017) all major alliances or members thereof are calling at Trieste, Koper, Rijeka and Venice. ICTSI, a major international terminal operator company (TOC) has forged a long-term jointventure to operate Rijeka port's container terminal (Adriatic gate d.d.), while a Polish logistics multinational (OT Holding) already holds a $20 \%$ share in Luka Rijeka d.d, the operator of all other terminals in Rijeka port. The Mediterranean Shipping Company (MSC) acquired a major stake in Trieste's container terminal (TMT). Total container throughput in NAPA has grown more than $250 \%$ since 2006 . Most noticeable growth has been observed in Koper, which now holds almost $40 \%$ of the total NAPA throughput. The development of container throughput and market share is provided in Figure 4.

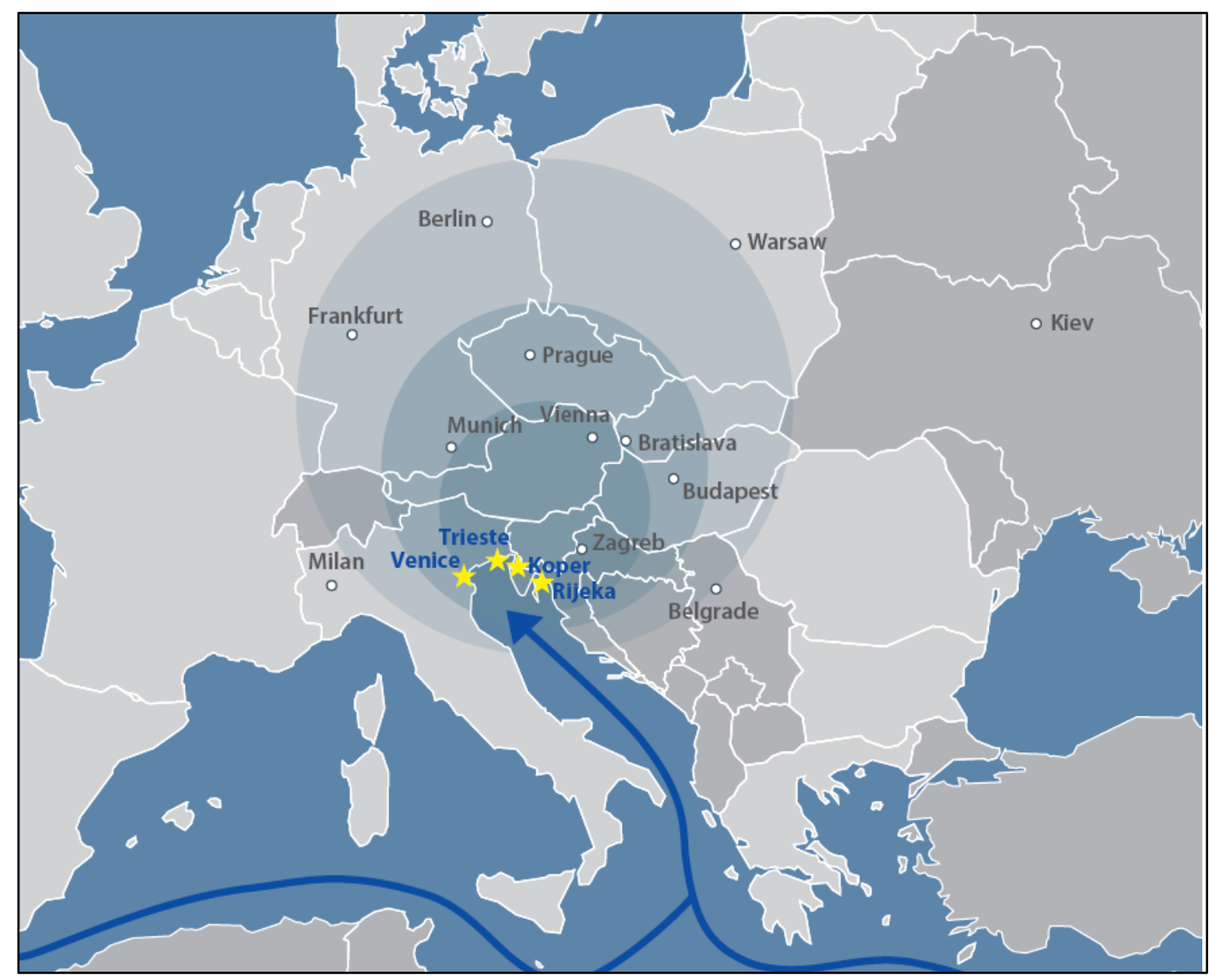

Figure 3: Location of the NAPA ports (Source: Port of Venice, 2015)

\footnotetext{
${ }^{10}$ Namely, certain respondents, if cited formally, would have to obtain approval from the institution's highest management on participation in the interview and for the answers provided, which could have influenced our research findings.

${ }^{11}$ The first author of this paper works with this forwarder.
} 


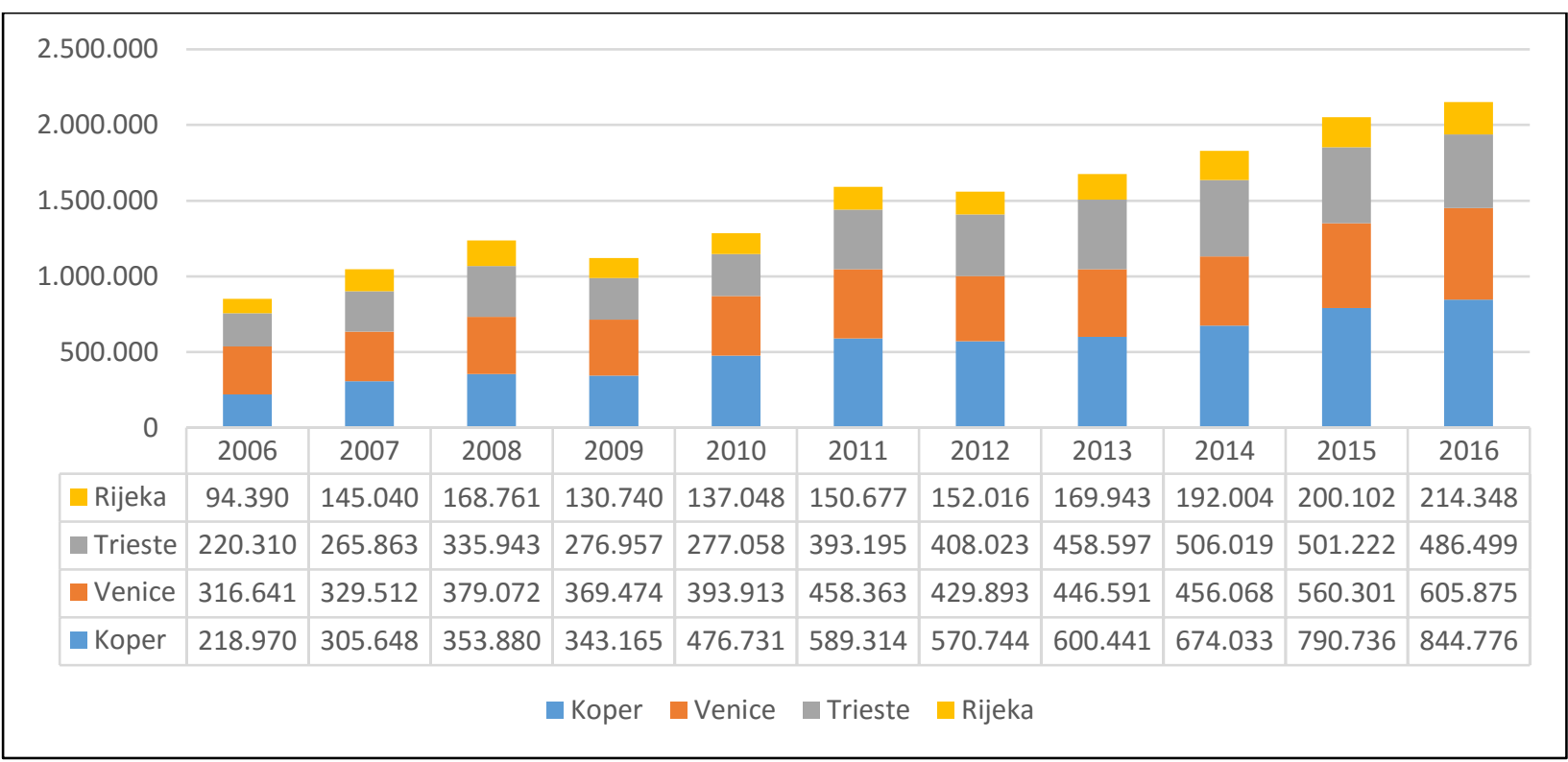

Figure 4: NAPA container throughput during the 2006-2016 period (Source: Port of Koper, 2017a; Port of Rijeka, 2017, Port of Venice, 2017a; TMT, 2017a)

Unlike the Italian (Genoa, La Spezia), French (Marseilles, Le Havre) or German ports (Hamburg, Bremerhaven), where industries in direct proximity of the port generate a large shipping demand, the NAPA ports actively aspire on serving contestable hinterlands in the Central and Eastern Europe (CEE), aside from their immediate vicinity. Interviews confirmed that these hinterland markets are the key interest of and represent major growth opportunities for all four NAPA ports. Thus, the NAPA ports not only face inter-range competition from the Hamburg-Le Havre region (Notteboom \& De Langen, 2015), but also compete against each other. This competition is not on a level playing field due to the differences in port policies and port management models (service port - Koper vs. landlord ports Trieste, Rijeka, Venice). ${ }^{12}$

Notteboom and De Langen (2015) point out that the NAPA faces scale disadvantages compared to the northern hub ports, which hinder the further development of the hinterland intermodal network. Acciaro et al. (2017) conclude that the full potential of the NAPA region is not realised because of the distorted perception of potential port users ${ }^{13}$ about the inefficiency and unreliability of the North Adriatic ports. This is congruent with Noteboom's (2010) finding that historical (the so-called 'memory' effect), psychological and personal factors influence the distribution of flows over ports.

The interviews with the shipping lines reveal that the shipping lines decide on the shipping patterns based on considerations for the NAPA region as a whole and much less so based on the potential of one individual port. After the decision on whether or not to call at the region, specific call pattern decisions for the NAPA ports are made. In this respect, the particularity of the NAPA is that it is somewhat remote from the major shipping routes, with generally no intermediate stops between a port close to the major shipping routes (such as Piraeus, Gioia Tauro or Marsaxlokk) and the NAPA ports. Thus, if a vessel is in the NAPA region, the cost of making an additional port call in the vicinity is relatively low, compared to the costs associated with sailing to the NAPA area in the first place. Our analysis reveals that due to the smaller ships used in the NAPA (9000 TEU) compared to North Europe (15000 TEU, see Figure $5^{14}$ ), slot costs for services to NAPA ports are higher (Notteboom \& Vernimmen, 2009).

\footnotetext{
${ }^{12}$ Finally, NAPA ports face a common threat due to new railroad connections from Piraeus port to CEE, which are planned and already partly active.

${ }^{13}$ In their case, manufacturers in the South German region.

${ }^{14}$ The comparison between Rotterdam and Koper is representative of the North European ports and NAPA respectively. NB: the Alliance does not operate deep-sea call services to/from the NAPA region.
} 


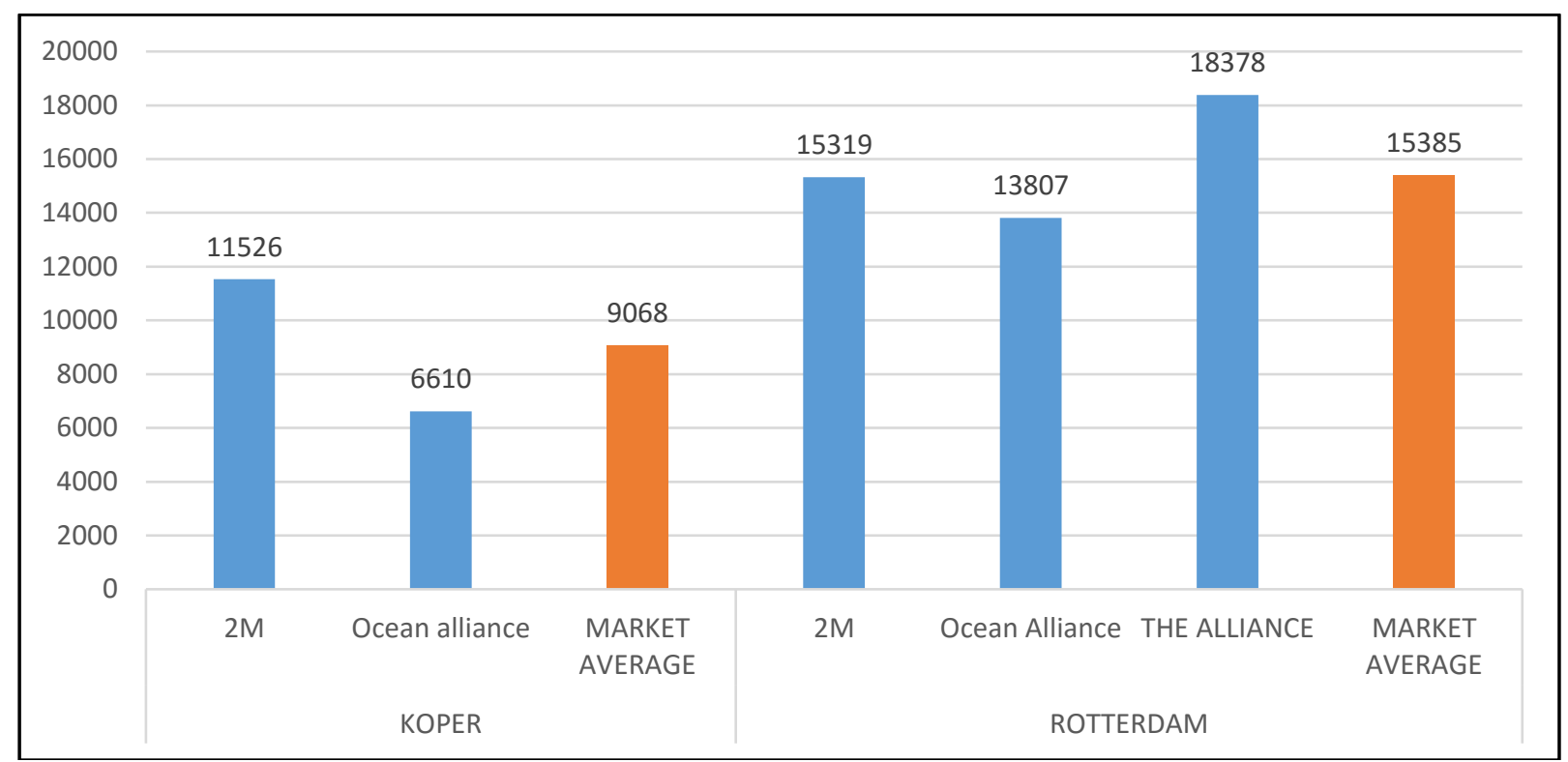

Figure 5: Average deep-sea container ship size in TEU (Source: CMA-CGM, 2017a; Maersk, 2017; YangMing 2017)

This is also confirmed by our comparison of westbound rates from Shanghai to NAPA and from Shanghai to Hamburg in 2015 and 2016. Despite the highly volatile rates in this period, we observe that the rates are approximate 100 US $\$$ higher in NAPA across the whole period (see Figure 6 and Figure 7). This is also in accord with the findings from a report of Drewry (2016).

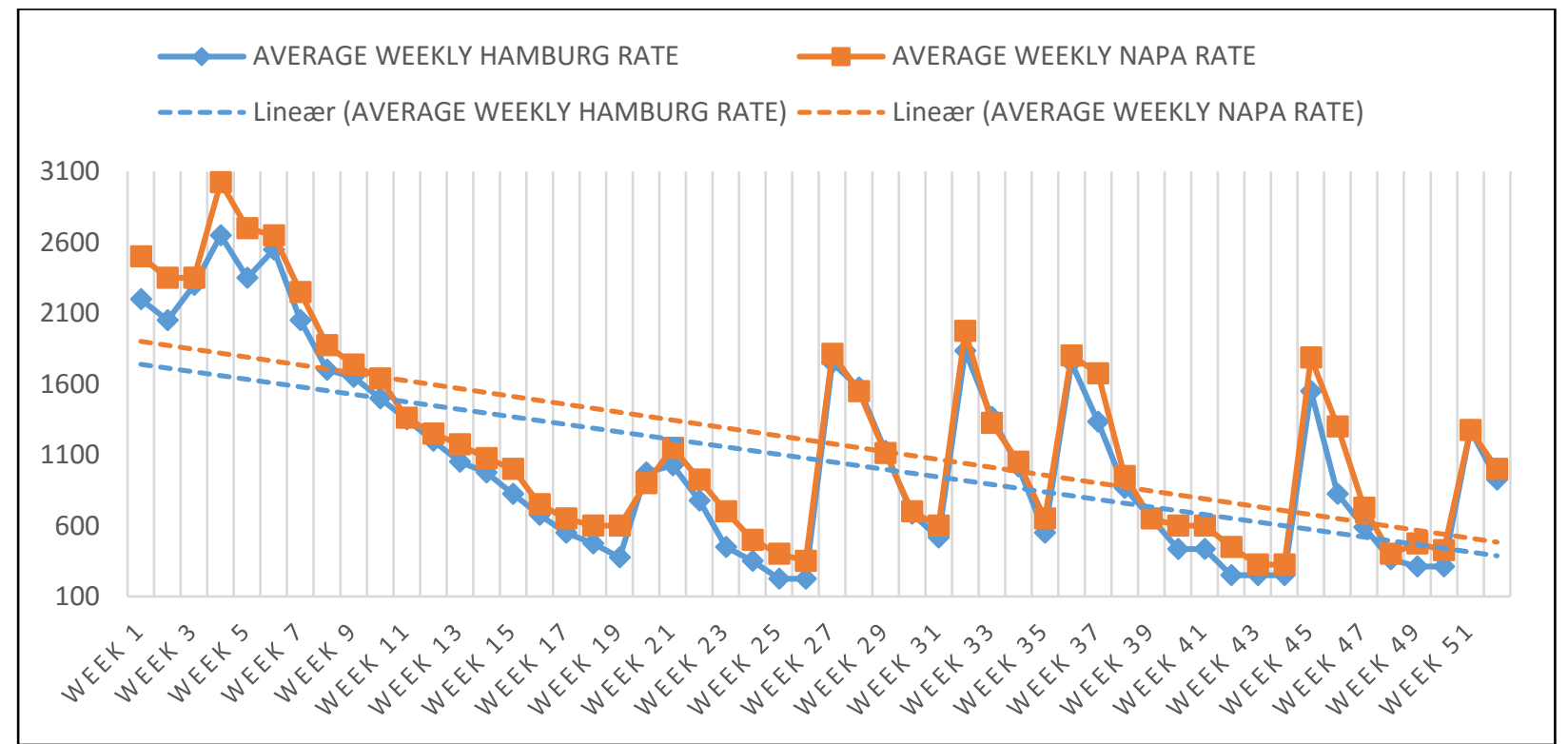

Figure 6: Average weekly rates on imports from Shanghai to Hamburg vs. Shanghai to the NAPA for $40^{\prime}$ container in 2015 in US\$ (own records) 


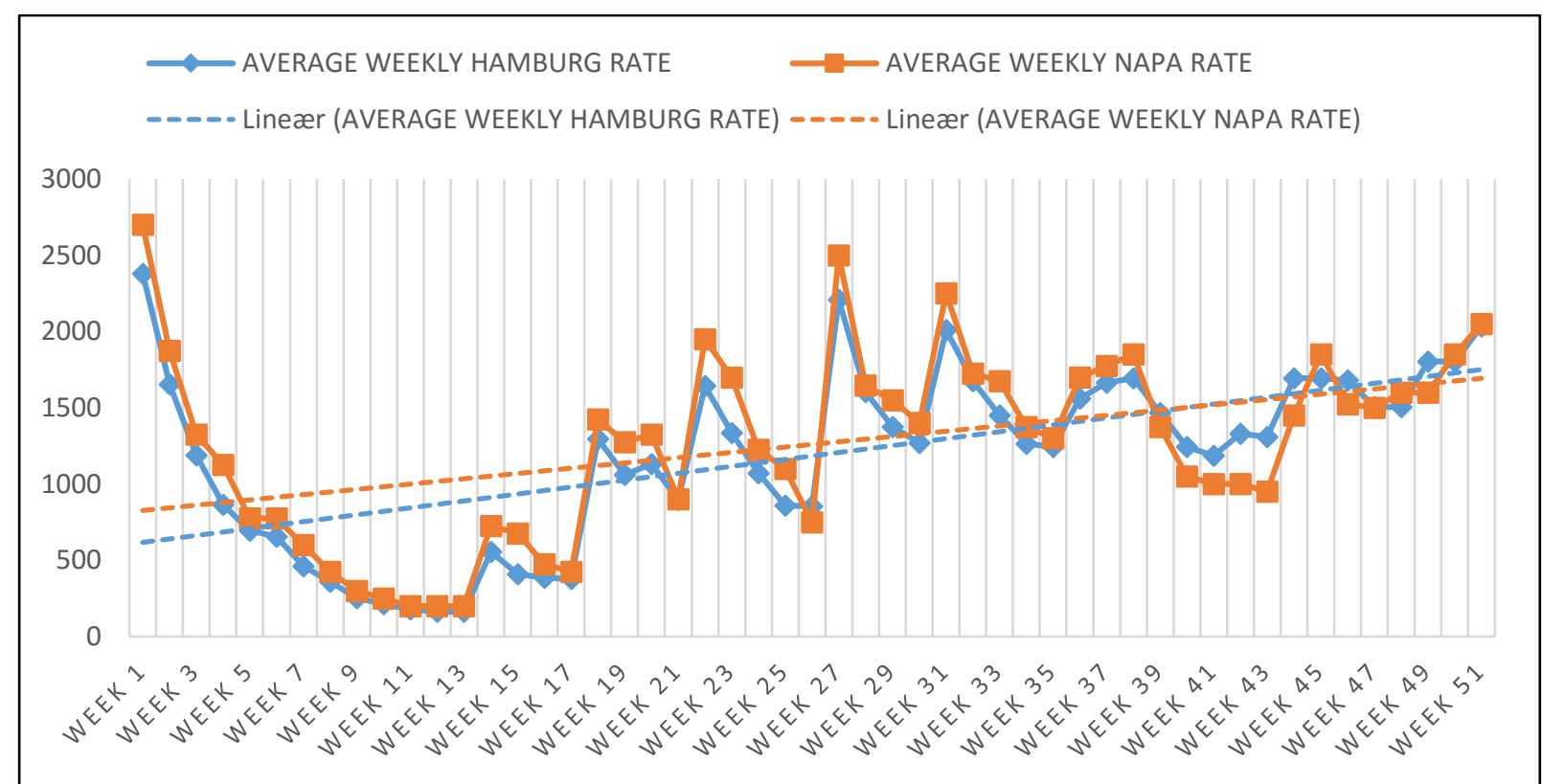

Figure 7: Average weekly rates on imports from Shanghai to Hamburg vs. Shanghai to the NAPA for $40^{\prime}$ container in 2016 in US\$ (own records)

Several further observations arise from analysing the service patters of the NAPA. Namely, there is still a huge gap between the NAPA and North European port connectivity levels. For example, the only deep-sea services that call in the NAPA region are from the Far East (Asia) - an example of this is shown in Figure 8 - all other existing services are short-sea and feeder services. No services connect the NAPA ports directly with South America or West \& East Africa. Furthermore, the vessel size that operate these deep-sea calls are on average 6000 TEU smaller than the ones operated in the North, as seen in Figure 5. Finally, only two (2M and Ocean Alliance) of the three major alliances call at the NAPA ports with deep-sea calls.

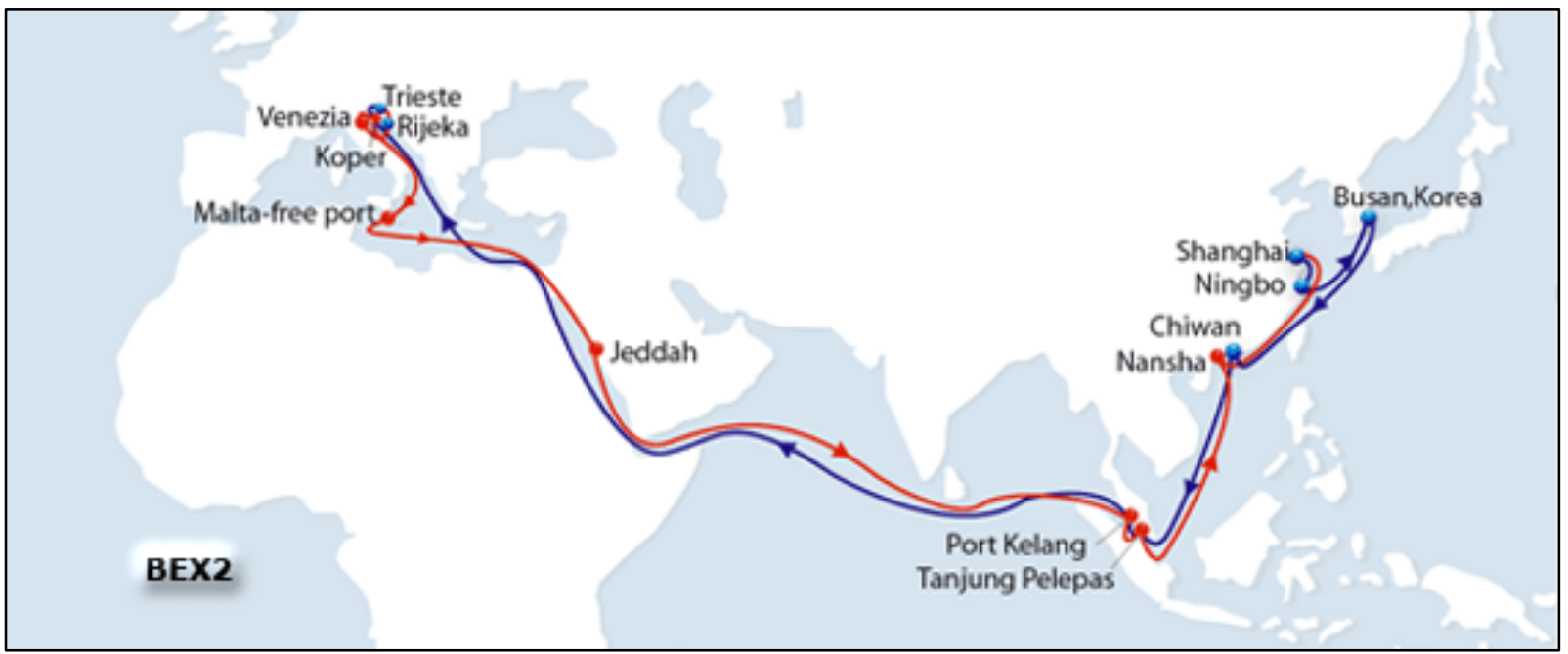

Figure 8: Phoenician express service from Asia to NAPA operated by Ocean Alliance (CMA-CGM, 2017b)

The limited connectivity is confirmed by comparing the liner shipping connectivity indexes. To ensure the comparability of our analysis, the indexes for The Netherlands and Slovenia are considered, since the main port in the Netherlands is Rotterdam and the main (and only) port in Slovenia is Koper, thus we can assume these results will be largely accurate for the individual ports of Rotterdam and Koper respectively. We observe the index to be around 96 for The Netherlands and around 33 for Slovenia (UNCTAD, 2017). This large gap in connectivity between the NAPA and North European ports is a huge 
disadvantage, but also considered an opportunity by the shipping lines and NAPA port authorities. Furthermore, by analysing the service patterns of the shipping lines, we observe two key findings. One is that the NAPA region is a turnaround region for shipping lines' service loops, meaning that they usually act as the last and the first call in a loop that returns to another continent, instead of an onward journey to other European destinations, as shown in Figure 8. This is because the additional sailing time into the NAPA region, in combination with multiple port calls, makes the product uncompetitive for potential onward ports such as Genoa or Valencia as the transit time would be at least 6 days longer than on services that do not call at the NAPA ports. Therefore, if the shipping lines do decide to call at the NAPA ports, the service loop calls at the NAPA as a turnaround region. Appendix 2 shows the current routing of the deep-sea services that operate from Asia to NAPA.

Following Notteboom's (2009) approach, we analyse the service patterns of the NAPA ports since 2010. All deep-sea calls always called at Koper and Trieste, regardless of the service loop or alliance. In fact, with the exception of the CYKHE alliance (which operated in the NAPA mostly in 2015), all deepsea services that have operated since 2010 always called at Rijeka as well. More recently, only the O3 alliance and today the Ocean alliance call Venice as well, while the $2 \mathrm{M}$ alliance serves Venice with a dedicated feeder vessel from Trieste. The interviews revealed that the main argument against calling at Venice as well is the insufficient draught. The service loop of the Ocean Alliance is such that only import cargo is offloaded in Koper and Trieste, with Venice at the last port of call, before export cargo is loaded again in Trieste and Koper thereafter. It therefore appears that shipping lines (at least in the Ocean Alliance) have made significant adjustments to their service loops in order to make the call in Venice feasible. Taking into account all the current container services (short-sea and feeder services) in the NAPA ports, we find that $94 \%$ of all services call at a minimum of two port pairs and $56 \%$ of services call at a minimum of three out of the four NAPA ports. The most frequent port pairs are Koper and Venice with $80 \%$ of all container services calling at both ports (see Appendix 2, Appendix 3 and Appendix 4). From this analysis, as well as from the expert interviews, we conclude that the main challenge for the NAPA ports is not attracting established NAPA services to their port, but rather attracting new services to the NAPA.

From the interviews with rail operators, we gather that they follow the cargo demand generated by the shipping lines' routing and service offer. Our analysis of the rail hinterland connectivity in NAPA (see Appendix 5) reveals that main overlap of markets is between Koper and Trieste (5 out 6 markets are served from Koper and Trieste, while 1 market, Hungary, is served from Rijeka as well); however, closer analysis shows that the frequency of trains indicates some level of market segmentation. Namely, Koper has a supremacy over the Hungarian, Slovakian and Czech markets, while Trieste leads the German and partly also the Austrian market. Our interviews further confirmed that with the exception of the Austrian market, the ports generally do not overlap, further proving the complementarity of the NAPA ports. Thus, based on the call patterns and interviews, we tentatively conclude that the NAPA is a case where the demand effect seems to be greater than the substitution effect, and in line with our conceptual approach, the ports are complementary. ${ }^{15}$ Three arguments justify this conclusion.

First, we have established that the call patterns reveal that all the ports are called at unless there is a draught issue (i.e. in Venice and previously also in Koper). This is a necessary condition, in line with Noteboom's (2009) postulation; however, it an insufficient one, because two ports with large captive hinterlands that compete for the same contestable hinterland are not complementary. Second, the joint market position vis-vis ports in other ranges can be improved, for instance with more deep-sea calls (e.g. South and North America). Given the need for sufficient volumes to make a 'turnaround service loop' economically viable, an increase of the available containers in one port actually increases the attractiveness of an NAPA call and thus increases the value of other ports. Third, even though there is clearly competition for serving the hinterland, the existing intermodal hinterland services are largely complementary with little market overlap. From this analysis, we can conclude that the relations between

\footnotetext{
15 This result differs from Twrdy \& Batista (2016), whose analysis is inconclusive, but does not work with the same conceptual approach to complementarity.
} 
the NAPA ports are complementary. This implies that all the stakeholders in the region benefit from a joint market approach.

\subsection{The NAPA cooperation}

Despite the complementarity, the cooperation of the NAPA ports and firms in the port cluster has been limited. The Port of Koper had a stake from 2000 until 2004 in the Trieste container terminal concessionary (Port of Koper, 2017a), since the Port of Koper did not have the capacities to grow and extend its infrastructure to handle containers at the time. The Port of Koper also intended to partake with a share in the General cargo terminal in Trieste, but unsuccessfully (OECD, 2011). The only clear cross-border port cooperation initiative, which is still currently active, is the North Adriatic Port Association (NAPA). The NAPA as an association was set up by the ports of Ravenna, Trieste, Venice and Koper in 2010. Later, Ravenna chose to exit the association and Rijeka joined it. Towards the end of 2017, Ravenna re-joined the association. The purpose of the association is to raise awareness and promote the NAPA ports as the gateway to Central and Eastern Europe. Aside from joint marketing activities, members also participate jointly in obtaining EU funding for a variety of security, environmental and ITconnectivity initiatives. Finally, the association also invests efforts in coordinating and lobbying for the development of road, rail and maritime infrastructure. The latter in particular has often been criticized, since investment projects are not coordinated, even on a national level between Venice and Trieste (see OECD, 2011), let alone on a cross-border level (e.g. a second rail track in Slovenia vs. a direct rail connection between Koper and Trieste $\left.{ }^{16}\right)$. Thus, while some level of pre-competitive cooperation does exist between the NAPA ports, there has been no commercial cooperation. This conclusion is supported by the expert interviews with port authorities and firms in the ports. Port authorities do cooperate on common marketing and awareness raising activities, EU funding for common security and environmental projects, the sharing of research and NAPA market analysis. The private sector interviewees point out that there is cooperation between port authorities, but no cooperation between commercial, private players. In conclusion, current state of the cooperation in the NAPA can be seen in Figure 11 - quadrant 1.

\subsection{Challenges for broadening the scope of and stakeholder involvement in NAPA port cooperation}

As set out in the previous paragraph, there is a case for NAPA cross-border port cooperation. Despite this, the cooperation of ports and firms in the port cluster has been limited. Expert interviewees provide several important issues preventing a larger scope of cooperation. For one, and despite EU membership, the NAPA ports follow different national policies and operate under different national legal frameworks. In the case of the Italian ports, until recently, even the differences in respective provincial administrations ${ }^{17}$ presented obstacles to cooperation. Since large infrastructural developments necessitate government involvement, long-term coordination on a multinational level is challenging, not least due to the relatively frequently changing nature of the governments in the respective countries. Furthermore, different port governance models complicate more strategic cooperation. The ports of Venice and Trieste are public sector 'landlord' port authorities, while the Port of Koper and partly the Port of Rijeka are commercially operating service port companies. This means that the latter ports are also concerned with commercial topics, which they would have to coordinate with different, private,

\footnotetext{
${ }^{16}$ The possibility of building a second rail track from Divača to Koper has attracted a lot of attention and debate in recent years (see e.g. ITF, 2015), as it is a relatively large infrastructure project development for the Slovenian economy, assessed to be worth over 1 billion $€$ in investment. The project was proposed more than a decade ago, since it was then estimated, correctly, that the container throughput via the Port of Koper would continue to grow, due to which the existing railroad would become insufficient and saturated. To increase the flow of containers by rail, a second rail track was proposed. As a possibly cheaper alternative, a rail link between Koper and Trieste was put forward, where Koper would then be connected to the Italian rail network. However, this proposal never obtained sufficient political momentum, particularly from the Slovenian side.

17 i.e. Trieste falls under the administration of the province Friuli Venezia Giulia and Venice falls under Veneto.
} 
terminal operators in Italy. Some respondents have raised the issue of differences in the cost of labour, the costs of running the ports, the costs of piloting and other nautical services in ports, which create unequal market conditions. Our respondents were unanimous that given all the obstacles, the NAPA as an association has achieved some important milestones and has indeed shown that cooperation is valuable. At the same time, they admit that the association is underfinanced and should be run autonomously. ${ }^{18}$ Finally, they claim, radical political and strategic decisions would have to be made for significantly increased cooperation to emerge, which they consider to be unlikely in the foreseeable future.

Since the port authorities have little influence over calling patterns or shipping lines, the involvement of private firms in the port cluster is necessary in efforts to initiate commercial cooperation. In addition, private firms have little, if any, incentive to develop deep non-commercial cooperation. Thus, in Figure 11 quadrant 2 and 4 do not present feasible options to expand cooperation. The only potentially feasible option is the joint involvement of port authorities and private firms, especially TOCs, in developing commercial cooperation. An example of such a cooperative market approach would be the joint approach of port authorities and TOCs to offer (temporary) rebates to shipping lines for developing new container services to the NAPA (after all, we have pinpointed this as a primary concern for all NAPA ports), when three or four ports are involved. Likewise, a NAPA-wide quantum rebate system for the shipping lines could be introduced, so that the overall NAPA costs would decline with increasing NAPA volumes. The issue with such strategies is that there is a need for collective action. We have discussed such potential initiatives with the respondents and the responses were generally reluctant. One issue at hand is that due to the involvement of shipping lines in terminal operations (Trieste's TMT) and in various alliances, a conflict of interests prevents providing rebates to e.g. a competing alliance. In addition, this interferes with the strategy of those ports that pursue a neutral market position (Koper).

Lastly, port specialization, albeit potentially attractive due to the already existing complementarities in cargo handling types among the NAPA ports (see OECD, 2011), would require some ports to stall their container ambitions, which is unlikely to be accepted by the local port stakeholders. It can be concluded that profit-oriented commercial stakeholders will opt to seek cooperation with one another if mutual interests (e.g. an increase of container throughput) are aligned. Figure 11 summarizes our findings about the future prospects of cooperation between the NAPA ports.

\footnotetext{
${ }^{18}$ Currently, the NAPA changes the presiding port every six months and it does not have a long-term leadership in place.
} 


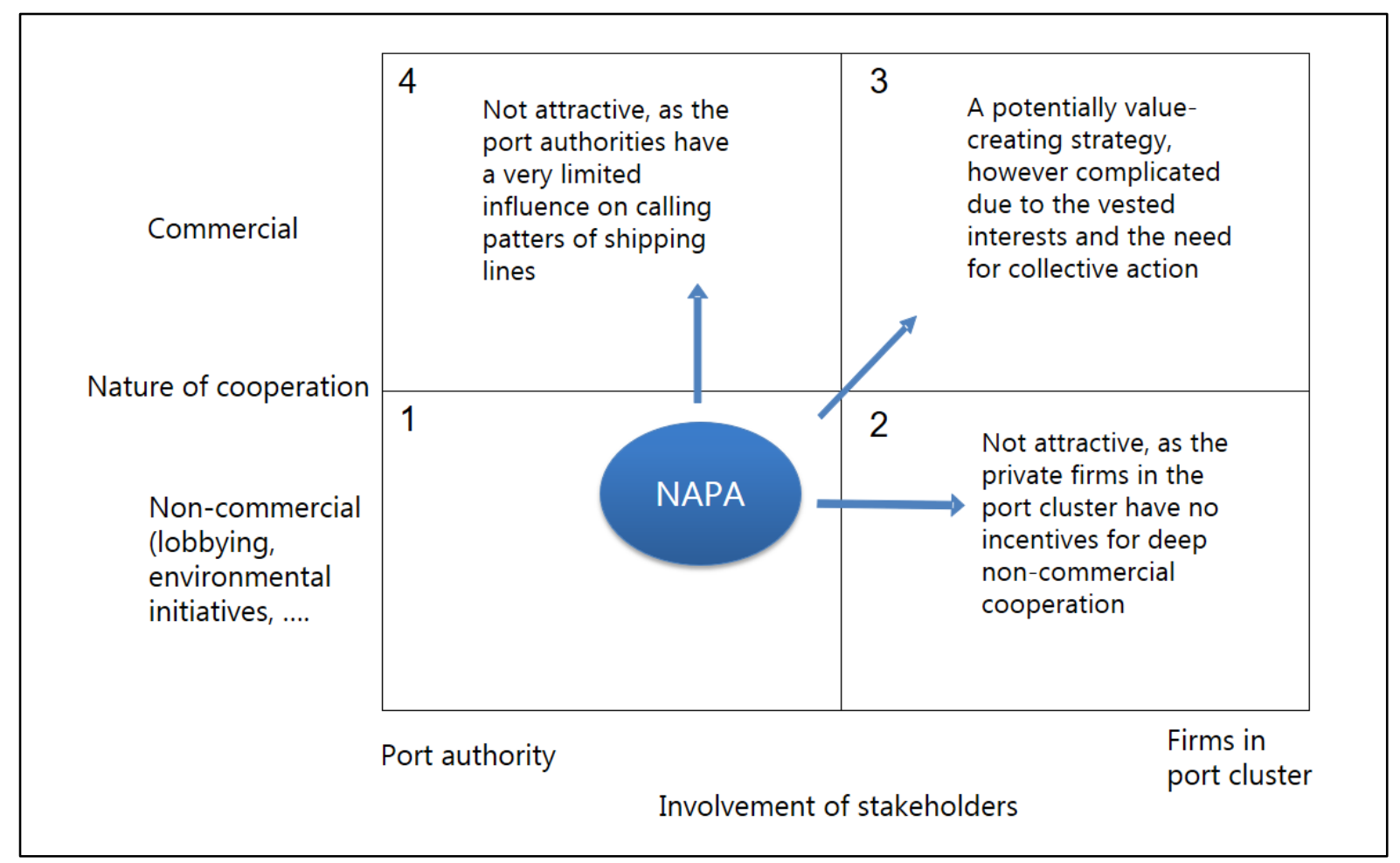

Figure 11: Port cooperation matrix: future prospects of the NAPA

\section{$5 \quad$ Conclusions}

A growing body of academic literature argues in favour of port cooperation, particularly in the case of adjacent ports. This paper analysed the NAPA ports, a good case of adjacent ports with a clear case for cooperation. The NAPA region is characterized by inter-port and inter-range competition. This inter-range competition intensifies with the initiative to connect the port of Piraeus with the CEE.

To assess the potential for cooperation, we provide conceptual rigour for the concept of complementarity. This paper postulates that in order to consider port cooperation among adjacent ports, the analysed ports must be complementary. We posit that the analysis of call patterns is a necessary but insufficient condition to establish complementarity. We argue that when the sum of the 'substitution effect' and 'demand effect' is positive, ports can be regarded as complementary. Next, we develop a cooperation matrix for classifying cases of port cooperation as an expansion of the existing models for analysing port cooperation.

In light of the challenges faced by the NAPA ports outlined above, we assess the scope and depth of the current cooperation between ports using the cooperation matrix. We operationalize our analysis using in-depth interviews with port authorities, terminal operators, rail operators, major shipping lines and forwarders present in the NAPA region. Our finding is that the current level of cooperation between NAPA ports and firms in the port cluster has been limited to non-commercial lobbying and joint marketing activities, with little or no signs of strategic alignment and commercial cooperation. We then proceed to assess the complementarity of the NAPA ports based on shipping line patterns and interviews with the shipping lines in order to establish the necessary condition for port cooperation. We find that the North Adriatic is a turnaround region for the shipping lines and that $94 \%$ of all container services in the NAPA call at a minimum of two port pairs, while $56 \%$ of all container services call at three out of the four ports. Secondly, we assess whether additional conditions are also met in the NAPA. We observe that the intermodal hinterland services are largely complementary. Also, given the need for sufficient volumes to make a 'turnaround service loop' economically viable, an increase in the available containers in one port actually increases the attractiveness of a NAPA call and thus increases the value of other ports. The NAPA ports would thus benefit from a joint marketing approach to attract new services to their region. Therefore, we conclude that the NAPA ports are indeed complementary. Finally, 
we consider the future prospects of cooperation in the NAPA ports from the perspective of the cooperation matrix. We observe that a potential value-creating strategy would be the joint involvement of port authorities and private firms, including TOCs, on the commercial front of cooperation. We propose several examples of such strategies. Nevertheless, due to the need for collective action with such strategies, we acknowledge that their implementation is complicated.

With these contributions, our paper builds on the growing literature favouring port cooperation. In addition, it expands the current level of port cooperation analysis, by offering an analytical tool that expands the scope of the analysed stakeholders, as the debate thus far has been limited to port authorities only. However, cooperation is only ultimately effective if grounded on commercial pillars, which is why the involvement of commercial stakeholders in this analysis is pivotal. We also extend the conditions that need to be met when assessing port complementarity. The cooperation matrix that we propose is universally applicable when analysing port cooperation in adjacent port clusters. We also discuss common challenges that complementary ports face when enabling greater cooperation. Policymakers and institutional decision makers on port strategies need to enable certain key conditions, which can spur cooperation between commercial stakeholders. Due to the dynamic nature of the maritime industry, further research and fine-tuning of existing models for assessing the level of port cooperation is expected and recommended. Finally, further research is also needed to explore additional cooperative market approach strategies. 


\section{References}

Acciaro, Michele, Bardi, Andrea, Cusano, Maria Ines, Ferrari, Claudio, \& Tei, Alessio. (2017). Contested port hinterlands: An empirical survey on Adriatic seaports. Case Studies on Transport Policy, 5, 342-350.

Casarini, Nicola. (2016). When All Roads Lead to Beijing. Assessing China's New Silk Road and its Implications for Europe. The International Spectator, 51(4), 95-108.

CMA-CGM. (2017a). Line services. [ONLINE] Available at: https://www.cma-cgm.com/productsservices/line-services. [Accessed 20 August 2017].

CMA-CGM. (2017b). Phoenician express. [ONLINE] Available at: https://www.cma-cgm.com/productsservices/line-services/flyer/BEX2. [Accessed 20 August 2017].

Donselaar, Pauline Wortelboer-Van, \& Kolkman, Joost. (2010). Societal costs and benefits of cooperation between port authorities. Maritime Policy \& Management, 37(3), 271-284.

Drewry Shipping Consultants. (2016). Market study: A 'best-route' market study for containerised imports to South Germany: Drewry Shipping Consultants Limited.

Fageda, Xavier. (2005). Load centres in the Mediterranean port range: Ports hub and ports gateway. Public Policies and Economic Regulation Research Unit, University of Barcelona.

Fremont, A, \& Lavaud-Letilleul, V. (2009). Rethinking Proximity: New Opportunities for Port Development. The Case of Dunkirk." Ports in Proximity: Competition and Coordination among Adjacent Seaports, 175-190.

Hoshino, Hiroshi. (2010). Competition and Collaboration among Container Ports. The Asian Journal of Shipping and Logistics, 26(1), 31-47.

Hwang, Cherng-Chwan, \& Chiang, Chao-Hung. (2010). Cooperation and competitiveness of intraregional container ports. Journal of the Eastern Asia Society for Transportation Studies, 8(0), 2283-2298.

ITF. (2015). A New Hinterland Rail Link for the Port of Koper? OECD Publishing.

Jacobs, Wouter. (2007). Port competition between Los Angeles and Long Beach: an institutional analysis. Tijdschrift voor economische en sociale geografie, 98(3), 360-372.

Langen, P. W. Peter de, \& Nijdam, M. H. (2009). A best practice in cross-border cooperation: Copenhagen Malmö Port. Netherlands, Europe: Aldershot.

Li, Jia-bin, \& Oh, Yong-sik. (2010). A Research on Competition and Cooperation Between Shanghai Port and Ningbo-Zhoushan Port. The Asian Journal of Shipping and Logistics, 26(1), 67-91.

Maersk. (2017). Schedules. [ONLINE] Available at: https://my.maerskline.com/schedules. [Accessed 20 August 2017].

McKinsey \& Company (2017). Container shipping: the next 50 years. Travel, Transport and Logistics. London: McKinsey \& Company.

Mclaughlin, Heather, \& Fearon, Colm. (2013). Understanding the development of port and regional relationships: a new cooperation/competition matrix. Maritime Policy \& Management, 4O(3), 278-294. 
MDS Transmodal. (2013). NAPA: Update of market study on the potential cargo capacity of the North Adriatic ports system in the container sector: final report: MDS Transmodal Limited.

Merkel, Axel. (2017). Spatial competition and complementarity in European port regions. Journal of Transport Geography, 61, 40-47.

Milgrom, P., \& Roberts, J. (1990). The economics of modern manufacturing: Technology, strategy, and organization. The American Economic Review, 511-528.

Noorda, Robbert. (1993). Co-opetition. Electronic Business Buyer, 8(12), 8-12.

Notteboom, Theo E. (1997). Concentration and load centre development in the European container port system. Journal of Transport Geography, 5(2), 99-115.

Notteboom, Theo E. (2009). Complementarity and substitutability among adjacent gateway ports. Environment and Planning A, 41(3), 743-762.

Notteboom, Theo E. (2010). Concentration and the formation of multi-port gateway regions in the European container port system: an update. Journal of Transport Geography, 18(4), 567-583.

Notteboom, Theo E, \& de Langen, Peter W. (2015). Container port competition in Europe Handbook of Ocean Container Transport Logistics (pp. 75-95): Springer.

Notteboom, T. E., \& Vernimmen, B. (2009). The effect of high fuel costs on liner service configuration in container shipping. Journal of Transport Geography, 17(5), 325-337.

Notteboom, Theo E, \& Winkelmans, Willy. (2001). Structural changes in logistics: how will port authorities face the challenge? Maritime Policy \& Management, 28(1), 71-89.

OECD. (2011). OECD Territorial Reviews: Slovenia 2011: OECD Publishing.

Roberts, J. (2007). The modern firm: Organizational design for performance and growth. Oxford university press.

Port of Koper. (2017a). Cargo Statistics. [ONLINE] Available at: https://luka-kp.si/eng/cargo-statistics. [Accessed 13 July 2017].

Port of Koper. (2017b). History. [ONLINE] Available at: https://luka-kp.si/eng/history. [Accessed 13 July 2017].

Port of Koper. (2017c). Sailing list. [ONLINE] Available at: https://luka-kp.si/eng/sailing-list. [Accessed 13 July 2017].

Port of Koper. (2017d). Railway connections. [ONLINE] Available at: https://luka-kp.si/eng/railwayconnections. [Accessed 13 July 2017].

Port of Rijeka. (2017). Statistika. [ONLINE] Available at: http://www.portauthority.hr/en/documents/Statistika+za+web+stranicu+-+ENG.pdf. [Accessed 13 July 2017]. 
Port of Venice. (2015). Opportunities for North Adriatic Ports. [ONLINE] Available at: https://www.port.venice.it/files/event/16mar2015-oppurtunitiesfornapa-koper-bulc.pdf. [Accessed 13 July 2017].

Port of Venice. (2017a). The port in figures. [ONLINE] Available at: https://www.port.venice.it/en/theport-in-figures.html. [Accessed 13 July 2017].

$\begin{array}{llll}\text { Port of } & \text { (2017b). Sailing } & \text { list. } & \text { [ONLINE] }\end{array}$ at: https://www.port.venice.it/files/page/1708venice-sailinglist_2.pdf. [Accessed 13 July 2017].

Rodrigue, Jean-Paul, Comtois, Claude, \& Slack, Brian. (2013). The geography of transport systems. Routledge.

Seo, Jung-soo, \& Ha, Yeong-sok. (2010). The Role of Port Size and Incentives in the Choice of Location by Port Users: A Game-Theoretic Approach. The Asian Journal of Shipping and Logistics, 26(1), 49-65.

Song, Dong-Wook. (2002). Regional container port competition and co-operation: the case of Hong Kong and South China. Journal of Transport Geography, 10(2), 99-110.

Song, Dong-Wook, Cheon, SangHyun, \& Pire, Christophe. (2015). Does size matter for port coopetition strategy? Concept, motivation and implication. International Journal of Logistics Research and Applications, 18(3), 207-227.

TMT. (2017a). Statistics. [ONLINE] Available at: http://www.trieste-marineterminal.com/sites/default/files/attachment/statistics\%20historic\%202003-2016_1.pdf. [Accessed 13 July 2017].

TMT. (2017b). Service routings. [ONLINE] Available at: http://www.trieste-marineterminal.com/sites/default/files/attachment/Services\%20routings.pdf. [Accessed 13 July 2017].

TMT. (2017c). Rail origins and destinations to and from Trieste. [ONLINE] Available at: http://www.triestemarine-terminal.com/en/rail-origins-and-destinations-tofrom-trieste. [Accessed 13 July 2017].

Twrdy, Elen, \& Batista, Milan. (2013). A dynamical model of container throughput of the North Adriatic Multiport gateway region. Scientific Journal of Maritime Research, 27(2), 361-367.

Twrdy, Elen, \& Batista, Milan. (2014). Evaluating the competition dynamics of container ports in the North Adriatic. Pomorstvo: Scientific Journal of Maritime Research, 28(1), 88-93.

Twrdy, Elen, \& Batista, Milan. (2016). Modeling of container throughput in Northern Adriatic ports over the period 1990-2013. Journal of Transport Geography, 52, 131-142.

UNCTAD. (2017). Liner shipping connectivity index, annual, 2004-2016. [ONLINE] Available at: http://unctadstat.unctad.org/wds/TableViewer/tableView.aspx?ReportId=92. [Accessed 20 August 2017].

Van Der Horst, M. R., \& De Langen, P. W. (2008). Coordination in hinterland transport chains: a major challenge for the seaport community. Maritime Economics \& Logistics, 10(1-2), 108-129.

Wang, James Jixian. (1998). A container load center with a developing hinterland: a case study of Hong Kong. Journal of Transport Geography, 6(3), 187-201. 
Wang, Kun, Ng, Adolf K. Y., Lam, Jasmine Siu Lee, \& Fu, Xiaowen. (2012). Cooperation or competition? Factors and conditions affecting regional port governance in South China. Maritime Economics \& Logistics, 14(3), 386-408.

YangMing. (2017). Long-term schedules. [ONLINE] Available at: http://www.yangming.com/eservice/schedule/LongTermSchedule.aspx\#ASI-EUR. [Accessed 20 August 2017].

Yap, W.Y., Lam, J.S.L., 2004. An interpretation of inter-container port relationships from the demand perspective. Marit. Policy Manag. 31, 337-355.

Yap, Wei Yim, \& Lam, Jasmine S. L. (2006). Competition dynamics between container ports in East Asia. Transportation Research Part A: Policy and Practice, 40(1), 35-51. 


\section{Appendices}

\section{Appendix 1: Interview questions}

a) Questions for shipping lines

1) Do you see benefits of NAPA as association and if so, can you specially describe them?

2) What could NAPA organization do more in your opinion?

3) Do you agree that NAPA region is a turnaround region?

4) What is minimum vessel utilization level for NAPA

5) Is it different compared to other European regions? If so, how?

6) What is minimum required revenue per container (both ways import-export) assuming average vessel size to NAPA is around 5000-7000 TEU for the deep-sea calls?

7) Do you consider NAPA ports complementary or substitutable?

8) If you had a dedicated terminal (either your own or a preferred partner/alliance), would you consider NAPA region more important than it is right now? If so, what is NAPA region potential compared to the Northern ports?

9) If NAPA ports cooperated by means of assigning one or two strategic ports for container cargo, would you see this as more or less beneficial? Should they do that?

10) What is the main obstacle more cargo is not being routed via NAPA ports? How would NAPA ports convince you to bring larger ships to the region?

11) If NAPA ports assigned one port to handle all region's containers, would this mean any particular changes from your perspective? Would you be able to include this single port in a different type of rotation, where it would be just part of another loop or it would still mean a turnaround point?

12) As a carrier present in all NAPA ports, do you coordinate your commercial activities for each port-market internally? How about within alliance members?

13) Are you part of any local/regional associations, which lobby and cater for better conditions, infrastructure, customs procedures, etc.? If yes, how successful is the organization/association in achieving results? What could be improved?

14) What would you suggest to the ports to do, to protect themselves from rapidly changing dynamics of supply chains in the region (Piraeus, rail connection with china, etc...)

15) Is there anything else you would like to tell us that will help us better understand the level of cooperation in NAPA region?

b) Questions for port authorities

1) Do you believe NAPA ports cooperate well, enough? If not, can you advise what is missing?

2) How restricted is the cooperation between NAPA ports given that ports are located and governed by three different countries and also different types of organizational structures (i.e. service port, landlord port, port authorities, etc.)?

3) If any of the members changed this, do you believe it would be easier to cooperate?

4) If we isolate container cargo only, could you describe how far-reaching is the level the level of cooperation between NAPA ports?

5) Do you believe NAPA ports are substitutable or complementary? Please justify your answer.

6) What are your future plans? Are they aligned with the strategies other ports have?

7) Specific: there are criticisms that for example Venice is battling with the issues of shallow sea, while Trieste has a naturally deep sea that there could be better alignment of development strategies? Trieste is also very strong in liquid cargo, while Venice is stronger

8) Could you describe in more details what exactly does NAPA association do? 
9) Do you see benefits of NAPA as association and if so, can you specially describe them?

10) What could NAPA organization do more in your opinion?

11) What is in your opinion key obstacle in increasing the level of cooperation level?

12) Do you believe there is more cooperation between for profit stakeholders like forwarders, rail operators etc. than it is on the level of port authorities?

13) Do you believe if all ports lied in the same country like Shanghai, Ningbo or Guangzhou ports do, would there be more cooperation?

14) Trieste has an advantage on bulk cargo. Koper clearly has advantage of RO-RO cargo. For Rijeka, we cannot emphasize any specific advantage. Do you believe ports could agree on which commodity group to specialize and thus not compete?

15) Academics argue that in the current world, where shipping lines are stronger than ever, cooperation makes more sense than competition, particularly in adjacent ports and particularly in complementary ports. Do you agree with that statement?

16) Would you rather see that major shipping lines divided ports for example Trieste with MSC, Koper with Maersk, Rijeka with Cosco and Venice with CMA and thereby solving the issue of competition between ports?

17) Actually, growth of container cargo in some ports has not been very significant. To what would you attribute that?

18) Is there anything else you would like to tell us that will help us better understand the level of cooperation in NAPA region?

c) Questions for rail operators

1) How well are the strategies among rail operators that operate in NAPA region aligned?

2) Would it be better for you if all container cargo for hinterland markets would be consolidated in one single NAPA port?

3) Would this be technically achievable?

4) What do you believe is the key issue preventing more growth in NAPA ports?

5) How could cooperation of rail operators contribute to achieving greater growth? If so, how

6) Is it important for you whether terminal operator in port is private or public?

7) Would it be beneficial if terminals were operated by shipping lines? Would this bring more competition or less?

8) Do you believe NAPA ports are substitutable or complementary? Please justify your answer

9) Are you part of any local/regional associations, which lobby and cater for better conditions, infrastructure, customs procedures, etc.? If yes, how successful is the organization/association in achieving results? What could be improved?

10) What would you suggest to the ports to do, to protect themselves from rapidly changing dynamics of supply chains in the region (Piraeus, rail connection with china, etc...)

11) Is there anything else you would like to tell us that will help us better understand the level of cooperation in NAPA region?

d) Questions for freight forwarders

1) What is the level of cooperation between freight forwarders in NAPA ports?

2) Could freight forwards facilitate greater cooperation between ports?

3) Do you believe if NAPA ports stakeholders cooperated more, would there be more throughput?

4) What are current activities you engage with other stakeholders?

5) What do you believe is the key issue preventing more growth in NAPA ports?

6) Do you believe NAPA ports are substitutable or complementary? Please justify your answer. 
7) Are you part of any local/regional associations, which lobby and cater for better conditions, infrastructure, customs procedures, etc...? If yes, how successful is the organization/association in achieving results? What could be improved?

8) What would you suggest to the ports to do, to protect themselves from rapidly changing dynamics of supply chains in the region (Piraeus, BRI, etc...?)

9) Is there anything else you would like to tell us that will help us better understand the level of cooperation in NAPA region?

\section{Appendix 2: Deep-sea services (Asia to NAPA)}

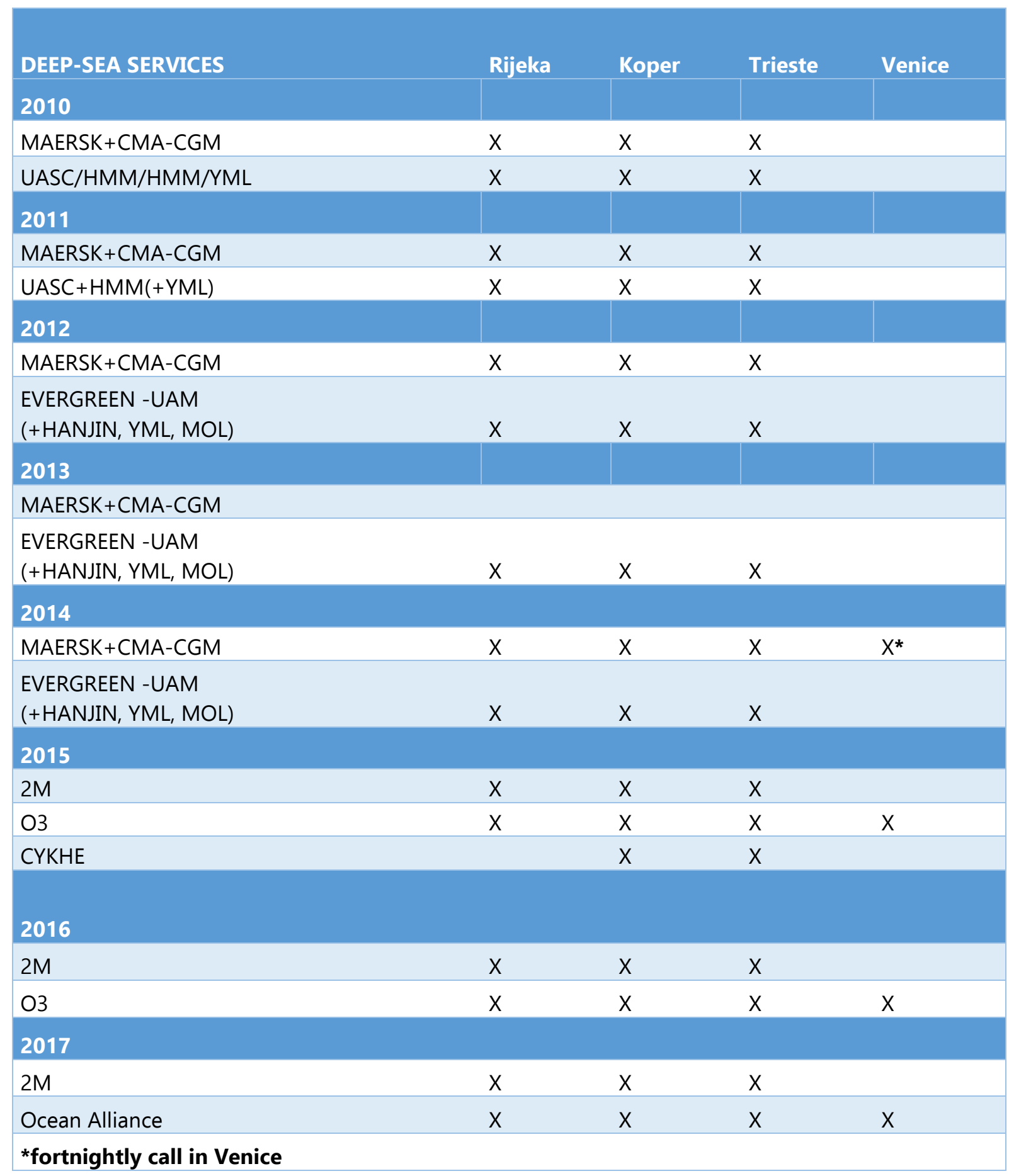

(Source: Port of Koper, 2017c; Port of Venice, 2017; TMT, 2017a; MDS Transmodal 2013; own records) 
Appendix 3: Short-sea and feeder services (intra-Mediterranean, North Africa, Middle East)

\begin{tabular}{|c|c|c|c|c|}
\hline SHORT-SEA + FEEDER & Rijeka & Koper & Trieste & Venice \\
\hline \multicolumn{5}{|l|}{ 2016-2017 } \\
\hline $\operatorname{cosco}$ & $x$ & $x$ & & $x$ \\
\hline ZIM & & $x$ & & $x$ \\
\hline MAERSK (49T Adriatic) & $x$ & $x$ & & $x$ \\
\hline HAPAG-LLOYD & $x$ & $x$ & & $x$ \\
\hline X-PRESS & $x$ & $x$ & & $x$ \\
\hline $\operatorname{cosco}$ & & $x$ & & $x$ \\
\hline MSC (Line B) & & $x$ & $x$ & $x$ \\
\hline MSC (Adriatic-Israel-Line A) & & $x$ & $x$ & $x$ \\
\hline MAERSK (A10 North Adriatic Shuttle) & & & $x$ & $x$ \\
\hline ARKAS & & $x$ & & $x$ \\
\hline EVERGREEN & & $x$ & $x$ & $x$ \\
\hline MSC (Adriatic to Cyprus-Line D) & & & $x$ & $x$ \\
\hline BORCHARD & & & & $x$ \\
\hline MSC (Adriatic to South Turkey-Line C) & & $x$ & $x$ & $x$ \\
\hline
\end{tabular}

(Source: Port of Koper, 2017c; Port of Venice, 2017; TMT, 2017b)

\section{Appendix 4: Port pair analysis}

\begin{tabular}{|lcr|}
\hline $\begin{array}{l}\text { TOTAL NUMBER } \\
\text { OF CONTAINER SERVICES }\end{array}$ & 16 & $\%$ \\
\hline PORT PAIRS & 3 & $19 \%$ \\
\hline KOPER-TRIESTE & 6 & $38 \%$ \\
\hline KOPER-RIJEKA & 13 & $81 \%$ \\
\hline KOPER-VENICE & 2 & $13 \%$ \\
\hline RIJEKA-TRIESTE & 5 & $31 \%$ \\
\hline RIJEKA-VENICE & 7 & $44 \%$ \\
\hline TRIESTE-VENICE & 7 & \\
\hline
\end{tabular}

(Source: own elaborations) 
Appendix 5: Hinterland rail services in NAPA

\begin{tabular}{|c|c|c|c|c|c|c|}
\hline Port & Austria & Hungary & Slovakia & Czech Republic & Poland & Germany \\
\hline KOPER & $\begin{array}{l}7 \text { train services, } \\
3 x \text { daily, } 4 \text { weekly }\end{array}$ & $\begin{array}{l}3 \text { train } \\
\text { services, } \\
2 \text { daily, } 1 \\
\text { weekly }\end{array}$ & $\begin{array}{l}3 \text { train } \\
\text { services, } \\
\text { mostly on } \\
\text { daily basis }\end{array}$ & $\begin{array}{l}4 \text { train services, } \\
1 \text { daily, } 3 \text { weekly }\end{array}$ & $\begin{array}{l}1 \text { service, } \\
\text { 2/week, }\end{array}$ & $\begin{array}{l}1 \text { daily } \\
\text { service }\end{array}$ \\
\hline TRIESTE & $\begin{array}{l}6 \text { train services, } \\
5 \text { daily, } 1 \text { weekly }\end{array}$ & $\begin{array}{l}1 \text { train } \\
\text { service } \\
\text { almost on } \\
\text { daily basis }\end{array}$ & $\begin{array}{l}1 \text { train } \\
\text { service, } \\
2 / \text { week }\end{array}$ & $\begin{array}{l}1 \text { train service, } \\
2 / \text { week }\end{array}$ & N/A & $\begin{array}{l}5 \text { train } \\
\text { services, } 4 \\
\text { almost on } \\
\text { daily basis, } \\
1 \text { weekly }\end{array}$ \\
\hline VENICE & N/A & $\mathrm{N} / \mathrm{A}$ & N/A & N/A & N/A & N/A \\
\hline RIJEKA & N/A & $\begin{array}{l}1 \text { train } \\
\text { service on } \\
\text { daily basis }\end{array}$ & N/A & $\mathrm{N} / \mathrm{A}$ & N/A & N/A \\
\hline
\end{tabular}

(Source: Port of Koper, 2017d; TMT, 2017c) 